\title{
COVID-19's Impact on the International Political Economy of Food Security in Sub-Saharan Africa
}

\author{
Gamel Abdul-Nasser Salifu ${ }^{1}$ \\ ${ }^{1}$ Department of Economics, School of Liberal Arts and Social Sciences, Ghana Institute of Management and Public \\ Administration, Achimota, Accra, Ghana \\ Correspondence: Alhaji Gamel Abdul-Nasser Salifu, Lecturer, Department of Economics, School of Liberal Arts and \\ Social Sciences, Ghana Institute of Management and Public Administration, Achimota, Accra, Ghana.
}

Received: October 1, 2020

Accepted: December 21, 2020

Online Published: March 5, 2021

doi:10.5430/rwe.v12n1p379

URL: https://doi.org/10.5430/rwe.v12n1p379

\begin{abstract}
International political economy of food security has become a central theme in the development narrative, providing a lens through which contemporary challenges of development are intergrated, rationalized and synthetized for sustainable and equitable development. The paper explores the prominent role of food security in development narratives, but in broader conceptions of state and its social contracts. From the analysis of the spatio-temporal evolutions of households' strategies for coping wth food insecurity and hunger, this paper clearly argues that food security defined as "access to enough preferred food" is fundamentally political. This study offers a set of different approaches to understanding the dynamics of food politics, grounded in broader theorectical traditions of power politics in food governance. The approaches are evaluated through an identification and analysis of a set of problematiques in food security governance gleaned from an overview of the major literature of note in food security and agricultural economics. The micropolitics of food that work in different constellations of ethnic power to perpetuate food insecurity are well outlined. The paper build upon this tensions by further questioning the regimes of power and how dominant political interests exercise themselves in corporate power structures, dismantling socially-oriented state approaches for enhancing food security. The relevance of intergrating the emerging dimensions of food politics and power, concerned with control of resources and opportunities for food production are also highlighted. With the politics of power not only concerned with material domination but directing rural people's beliefs, values, behaviours and practices. As well as elaborating on the dorminant issues of food politics that have co-opted to increase food insecurity, the paper outlines alternative visions that are diverse and even incompatible on epistemological grounds. In so doing, the paper argues for triangulation of new ideas to shine the light from different angles to achieve sustainable and equitable food security in the Covid-19 era of food crises and deprivation. In this vein, the review, examines the impact of the mobility restraints set in 2020 by local governments to stem the spread of COVID-19 (SARS-CoV-2) on food security regimes in Africa, with particular emphasis on how the move has disrupted economies worldwide, disproportionately affecting livelihoods already threatened by poverty and hunger. Whilst the sections heretofore articulate the synergies between food and politics, so much is shared that this review reflects a richer picture of the political economy of food security on the international front.
\end{abstract}

Keywords: food security, household metrics and indices, food politics, power structures, sustainable livelihoods, productive capital inputs, economic shocks, Covid-19 pandemic

\section{Introduction}

The internationational political economy of food security remains a crucial issue of the sustainable development agenda because it offers the most comprehensive lenses through which agicultural economists and policy analysts intergrate and address a range of contemporary global challenges associated with food security. This article addresses in particular the interrelationships between food and sustainable equitable development arguing that food is fundamentally political (Salifu, 2021). Food politics have captured high levels of attention in international policy debates and among global, national and local actors (Brück, \& D'Errico, 2019).

The international food policy debates have primarily focused on new discussions of global food security. The issues have addressed vital aspects of production, reproduction, distribution, consumption and the dynamic synergies between these, across global, national and local food regimes (Cai et al., 2020). The food policy debates have also 
incorporated discussions of the fundamental roles of the economy, state -society relations, environment as well as personal, social, cultural and identity dimensions of food consumption (Anaman, 2018). Because food is a basic need and necessity of life that must be satisfied before all other concerns, the food security agenda remains capacious in global policy debates, providing the vital inter-conjuctions by which to intergrate and address a range of contemporary development issues (Chamberlina \& Jayne, 2020). Yet food is also a political matter, with questions of how food systems are constituted, how they change or (do not change), who gains or loses, implicating power relations. As modern systems prove themselves neither sustainable nor equitable, with profound intergenerational consequencies for human wellbeing and prosperity, these politics have become highly charged. An intense politics of food security is unfolding across global cultures of the world (Malang \& Holzinger, 2020).

There are long standing intersections between food and international development policy, rhetoric and action (D'Errico, Romano, \& Pietrelli, 2018). The Malthusian concerns with feeding global populations dominated colonial and post-war development and structured many policy approaches, extending from agriculture to environment, science and technology, infrastructural investment, population control and trade (Deaton \& Lipka, 2015). Many of these later consolidated in the creation of international -based organisations, The Food and Agriculture organisation, (FAO), The World Food Programme, (WFP), and the International Fund for Agriculture Development (IFAD).

Since 2015, the United Nations Sustainable development Goals (SDGs) has come to dominate policy discourse and action. With the adoption of Agenda 2030, the international community committed itself to the eradication of hunger and to achieving other important goals, including making agriculture sustainable in production and distribution, reducing inequality in both production and consumption of food, and making economic growth inclusive (Sarkodie, \& Adams, 2020). It is increasingly being recognized that the place of food goes beyond zero hunger to encompass synergies and tensions with many other goals. Nevertheless, high levels of political rhetoric belie these laudable aspirations.

New estimates show that global food insecurity remains stubbornly high, with almost 2 billion people continuing to suffer from hunger (FAO, 2019). Obesity is rising, and micronutrient deficiencies have grown and unhealthy diets are now considered the leading global cause of non-communication diseases. By focusing on the international political economy of food security, the paper seeks to show how politics, power, and social justice might be brought more fully into these growing international concerns about food, hunger and equity. Food security improvements in rural Africa have become deeply political, that the article aims to contribute to a more transformational politics of food that are more sustainable and equitable in the era of Covid-19 pandemic.

To achieve this goal, the international political economy analysis of food security is driven by two major factors; First, as a sequel to the attainment of global change and sustainable development by 2030 (World Bank, 2020). Second, as a response mechanism to emerging crisis of rural unemployment and food insecurity status of households accentuated by the COVID-19 pandemic (Laborde, Martin \& Vos, 2020). To fully appreciate the significant impact of the two forces on food security outcomes of rural poor in Africa, it is important to establish the traditional foundations that have guided rural livelihoods and food security policy objectives in the developing world (Laborde, Martin, \& Vors, 2020). This preliminary assertion is important because the forces have acted to crystallize the emergence of food security as a global theme for poverty reduction and betterment of the human condition around the world. Consequently, the preamble for the universal declaration of food access as a fundamental human right was established and ratified by all governments of the world (World Bank, 2020; United Nations, 1948).

The declaration guided global discussions on the need to maintain healthy and well nourished populations to enhance adequate survival of the human race (Devereaux, Bene, Hoddinott, 2020). The ratification of food security rights surged new interests in sustainable enhancement of global food security (Bickel, Nord, Price, Hamilton \& Cook, 2000, Bene, 2020). It was also instrumental in counteracting the devastating impact of the African famine in the 1980s that resulted in deterioration of basic human needs (Reardon, Delagado \&Matlon, 1992; Moniruzzaman, 2020).

Since the declaration, the international community in partnership with development economies has tried a series of different approaches to avert a repetition of similar crisis which truly marked a dark period in global development work and co-operation. These different approaches have clearly reflected the changing themes and definitions of global food security emphasis from the early 1950s to the latter part of the 2000s (Narayanan, 2020). However, these different perspectives of food security have not decomposed the growing complexity and challenges of reconceptualizing food security as global theme, but in many cases complicated the efforts to incorporate the new dimensions of food for jobs and incomes.

At best sustainable food security concepts have intergrated some of the important dimensions of food availability, 
access, utilization and stability. To a large extent, food security researchers have radically departed the emphasis of sustainable national food sufficiency to achieving global household food security for all rural populations. However, the aspects of food security analysis which address rural food access from a qualitative perceptive of access to jobs and incomes in rural Africa, has not been fully addressed by development research. This has created the need for a revisionist conceptulisation of food security to reflect access to jobs and incomes within the broader framework of political economy which intergrates a differentiated- unity approach to a synthesis of a better approach.

This reconceptualization drive to intergration of jobs and incomes in food security analysis is triggered by the fact that conventional wisdom of food security has not placed the rural household at the centre of its activities. A revisionist approach to food security emphasizes a detailed intergration of livelihoods activities into food security policy designs (Abebaw, Admassie, Kassa \& Padoch, 2020). Within the new context of globalization, localization, and sustainable livelihoods, the concept of household food security becomes extremely crucial. In otherwords, assessement of the completeness and comparability of food security outcomes is essential to overall food security analysis (Allanson, Kasprzyk, \& Barnes, 2017).

Understanding the political economy of global food security from a revisionist perspective creates the possibility of clarifying the emerging confusion surrounding food security analysis. The study of the international political economy of food security is made necessary by the need to re-inform policies for poverty alleviation in rural Africa. Given that over $80 \%$ of Africa's rural poor are engaged in agriculture, it is expected that analysis which focus on rural livelihoods would play a significant role in poverty alleviation strategies. The analysis is also meant to support a new understanding of the potential impact of political economy analysis in the attainement of food security. It is also important to state that when wider theorization of food security is combined with political implications of development, it provides a deeper engagement for rigorous analysis of food security status of Africa's poor. It also provides a rare opportunity for political re-positioning of poor households to receive targeted support for food security enhancement and welfare.

The purpose of this paper is to clarify the concept of political economy analysis of household food security as a fundamental tool to effective, sustainable and resilient poverty reduction in the developing world. Without seeking to underestimate the relevance of current approaches of food security to poverty reduction efforts, the international political economy analysis from a revisionist perspective complements the sustainable livelihood framework and holds both the methodological and theoretical keys to effective management and administration of food security policy interventions in Africa.

The main objective of this review is to assemble the various concepts of the international political economy of food security that provide cross-cultural and multidisciplinary approaches in understanding food security as a fundamental human right. This paper is structured around several themes. The next section deals with classification of food security and the measurements of food security from Malthusian perspective to modern era of technological innovation under the Green revolution. This is followed by discussion of the growing vulnerability of households to food insecurity and the major drivers of food security. This is followed by discussion of strategies used by households to attain sustainable and resilient food security in their anthropological context. The conclusions and references form the final part of the paper. This paper contributes to the international political economy literature by providing a synthesis of research works undertaken over the last 70 years and indicating gaps in the literature which may prompt new research works to advance local food security governance, leadership and administration as an important policy tool for poverty reduction around the world.

\section{Malthusian Food Security in the $20^{\text {th }}$ Century and the Green Revolution}

If food security is the "mother" of all subjects of agricultural economics, then Malthus is credited as having played the role of the "father" of food security. This is justified by the fact that the beginning of the discussion of food access in relation to population demographics had to principally deal with Malthus's idea of food production being unable to match up population growth and eventually leading to food insecurity and starvation. Malthusian concerns, about feeding the world's growing population have been central to the international discourses on food security. Although, Davis (2017) argues that the introduction of Malthusian ideologies increased rural poverty and exacerbated hunger in Brazil, China, Ethiopia, India and the Phillipines. Feeding hungry people is a moral imperative and a long standing issue for global development, currently expressed in the SDGs. The goal has driven agricultural innovation aimed at food production. It has shaped the architecture of food security research in ways that have been particurlarly influential in sub-sharan Africa.

Food shortages and famines in Asia in the mid- $20^{\text {th }}$ century laid the foundations of green revolution, considered the most important breakthrough in food security analysis and agri-food technology innovation of modern times (Oshaug, 
1985). The green revolution is touted to have marked the turning point for global food security systems across many countries of the world, experiencing intensification around high-yielding crops and growing interaction between production, processing and trading. The science driven technology innovation of green revolution in 1960s-80s resulted in unprecedented rises in global cereal outputs often celebrated by agronomists and economists as "food-access" revolution in India, Brazil, and China (Mulwa, \& Visser, 2020). An evaluation of international political economy of food security in that era showed that, green revolution was not just about technological innovation to increase yields; it was crucially about cold-war geopolitics, nation-state building, and state capital alliances (Tithy, Naznin, \& Elias, 2017).

Class politics and ethnicity was also at the core of green revolution (Raphael, 1967). In India for instance, the transition from green revolution early days of plant-breeding into biotechnological era since the late 1990s, was marked by a growing role of private transnational corporations in funding research (Upton, Cissé, \& Barrett, 2016). The starving rural populations under unfair "caste systems' were not the principal target of agricultural research and funding. The green revolution centred on global markets rather than national and household food self-sufficiency (Marafa, May, \& Tenebe, 2020). The politics and geopolitics of state and corporate power and class dynamics of food security created the need to inculcate new institutional multidimensional approaches to food security analysis commonly constituted into a body of knowledge reffered to as the political economy of food security (Dithmer \& Abdulai, 2017). International political economy therefore acknowledges the knowledge politics of scientific innovations in food production and the dynamics of power that determine whose ideas and technological ideas prevail. In recent times, analyisis of the environmental and social cost of green revolution has also emerged pointing towards the political ecology of food security in village Africa.

\section{The Universal Declaration of Food Rights}

The right to food is well elaborated in Articles 22 to 27 of the preamble to the United Nations' Declaration of Human Rights adopted by the General Assembly of the United Nations in 1948. The declaration stresses the fundamental rights of all people at all times to quality food irrespective of race, gender, religion or status (United Nations, 1948; Bene, 2020). This fundamental right places great intergrity in the observation of human values which support entilement to food (Eide, 1986; Devereaux, Bene, Hoddinott, 2020). This entilement among other entilements is fundamental to human existence; however, the fundamental right to food remains the central right of all rights. This is essential because without equal access to food at all times by all members of society, society as a basic structure of humanity ceases to exist. This surely threatens stability and social order resulting in food conflicts and wars. This is why, food security remains a central issue of social and ethnic conflicts of rural people (Brück \& d'Errico, 2019).

The new approach to resolving the crises of food insecurity is to adopt a revisionist approach to analysis of food security needs of global citizenry. This solemn act of intergration recognizes the fundamental role of society in safeguarding the interest of citizens to common property resources which enhance the ability to produce and secure food. The state is expected to spearhead the co-ordinative efforts of national, sub- regional and national food security drives. By this, the national government is expected to honour commitments regarding protection of food rights and individual entilements to quality food. What makes the political economy approach a fundamental human right approach is elaborated by the support it lends to enactment of global and local legislations to enforce the measures for improving food security. The political economy approach is held in high esteem for its respect for human food rights and entilements as well as the key role it plays in compelling states to allocate at least $10 \%$ of the national budget to addressing food security concerns of citizenry. Many development scholars and policy makers around the world have pushed for more political economy reforms in efforts to achieve food security and sustainable economic growth.

\section{Definition and Classification of Food Security Needs}

The operational definitions and principal underpinnings of the international political economy of food security are well elaborated by the influential works of Siamwalla and valdes (1980), FAO (1983), and the World Bank (1986). In these works, a wide range of conceptual factors related to food security analysis have been clearly outlined for a thorough political economy analysis of food security.

The major grounding themes featured in the definitions, certainly offer important insights for improving multi-stakeholder analysis of food security. The issues highlighted include: 1) The definition of food security as ability of households to be self-sufficient in food production through own production 2) ability of individuals to purchase enough food to meet consumption needs through enhanced market participation (Narayanan, 2020). 


\subsection{Food Security as Sufficiency}

Food security visualized as the ability of households to produce enough food to meet own consumption is seen as a crucial objective of all national food self-sufficiency programmes. A nation is said to be food self-sufficient if its poorest households are meet their annual food production needs without having to rely on cheap rice and poultry imports from China and Brazil. Food sufficiency therefore reflects a state in which the nation's own food production is enough to meet local consumption needs of households without seeking external food aid or supply from advanced countries. In other words, food self sufficiency of a nation is well tied to enhancning the mechanisms for raising the productivity levels of staple food needed to assuage and smoothen domestic consumption patterns (Maxwell, 1990; Ahmed, \& Gasparatos, 2020). In line with this objective, several interventions have been made by government parastatal agencies in Africa to modernize small-scale agriculture characterized by sluggish growth and low factor productivity often linked to environmental degradation. Since the late 1980s, African governments including Ghana have implemented macroeconomic policies and sectoral reforms to improve food security. However, the agricultural sector remains challenged by logistical problems to fully drive the food security agenda. Hence food insecurity is a serious problem in rural Africa, with many farmers unable to respond to new agricultural programmes such as Ghana's flagship programme, Pplanting for Food and Jobs programme (PFJ).

Many nations of rural Africa have failed to meet its staple food production targets. The consistent cereal food production deficits and occasional shortages make the idea of food sufficiency a far off objective to be attained by most nations. Rural households have consistently struggled to meet basic food consumption needs under many food self-suffieciency national goals. Hence, a political economy analysis of food security has always advocated a better concept that widens greater access of all people to food. This approach has also called for food security concepts to take into consideration the anthropometric needs of individuals of the household in national planning efforts for meeting food security goals. Inspite of the rhetoric, national food security actions are still not adequate to meet food consumption needs. It is important to emphasise that even under conditions of meeting targeted national food consumption needs, it still does not constitute an attainment of food security for all households. This is because national food sufficiency cannot be equated with attaining household food security. The two are quite different in the developing world especially under circumstances where members of the household have different dietary needs due to the peculiar nature of their climatological and socio-economic environment (d'Errico, Romano, \& Pertrelli, 2018). Hence accessing food through the market remains the only practical option for addressing food security needs of different household agents.

\subsection{Food Security by Market Access}

Food access defines that dimension of food security which offers complete access to quality food through open market purchases. If rural households are not able to produce all their food requirements due to climate change and weather shocks, the obvious alternative is to purchase the food they need. These purchases are guaranteed to last the households a significant period before new purchases are made. For food access security to meet the needs of the entire households, rural people are required to earn adequate incomes from the pursuit of income generating economic activities through market participation. Food security is therefore related to income earning capabilities of the household generated from a set of economic activities undertaken by the household. Under ideal conditions of market success, households are able to earn adequate incomes to purchase all their food requirements. However, if market failure abides, which is usually the case for large proportion of African farmers, food consumption is severely reduced, as low incomes are inadequate to meet food expenditure. Consequently, they purchase less food and remain food insecure throughout the production cycle. The literature evidences that even under the ideal situations, when farmers earn adequate incomes from pursuit of profitable economic activities, they are still chronically food insecure due rising cost of food, food price volatility and macroeconomic instability regimes of their respective countries.

All in all, food security of low-income households is significantly driven by the real income earnings of households vis-a-vis, food prices and purchasing power of money. Therefore food security of households can only be improved by market correction approaches which increase market access of households either through exploitation of the current market niches or through engagement in new proactive and entrepreneurial economic activities which yield higher income earnings to support adequate food consumption. This increases the resilience of households to chronic food insecurity caused by market failure and low earnings.

This is why the most dominant approach to enhancing sustainable food security in rural Africa has remained largely market- access-oriented. Eventhough the concept of Food security was borne out of the raging debates of the World food conventions in the early 1970s (Gillespe, van den Bold, 2017; FAO, IFAD, UNICEF, WFP, WHO; 2019), the struggle for total food access by poor communities has dominated the discussions in recent times. This has broadened 
the discussions on how to feed the growing future generations as well as improve the standardization techniques for excellent quantification of food security metrics (Barrette, 2010).

Food security particularly courts governments' attention because recent evidence suggests that Africa is facing population boom, nearly quadrupling it by the next half century. The population research bureau has indicated that Africa's population would more than double to 2.4 billion by 2050, with sub-saharan Africa, currently 900 million plus, swelling to 2.3 billion.

The prospect of so rapid a rise has triggered a host of Malthusian fears on the food security status of the continent and elsewhere. This has ignited fresh discussions with international organisations adopting new harmonsation approaches, partnerships and collaborations with local and global actors to stem the tide of growing food deprivation in major parts of the developing world with focus on rural Africa (Baliki, Bruck, \& Stojetz, 2018).

Within and outside the borders of nations, effective linkages between state, market and community actors on how to enhance food access remains the objective of political economy discussions of food security around the world (Chamberlina \& Jayne, 2020). It is the contention of this paper that enhancing political economy attributes of food access would spearhead effective collaborations for targeted support from state and international organisations such as the World Food Programme (WFP), IMF and World Bank to improve food security (Harrigan, 2014).

\section{Measures of Household Food Security}

The methodologies for estimation and quantification of food security has long transitioned from an objective analaysis food poverty and deprivation thresholds of households to the analysis of the subjective perceptions of food deprivation and hunger. In food security research, the estimation of the subjective perceptions of hunger is either quantified as single dimensional indexes or multiple -dimensional models and indicators (Pinstrup-Andersen, 2009).

The food security literature identifies different set of approaches for estimating household food security. In otherwords, evidence outlines the measures for assessing the hunger status of rural people at all levels. At the macro or micro levels, food security can be conveniently derived qualitatively or quantitatively using several constructs identified in the economic literature of household food security (Headey \& Ecker, 2012). The Major constructs include: (1) The Household Hunger Scale (HHS), (2) Household Dietary Diversity (HDD), (3) Household Food Insecurity and Access Scale (HFIAS), (4) Coping Strategies Index (CSI), (5) Food Consumption Score (FCS), (6) Anthropometric Measure, (7) Self-Assessment Measures, and (8) the Global Hunger Index (GHI) (Ike, Jacobs, \& Kelly, 2017; Headey \& Ecker, 2012). These measures are briefly defined and discussed in the next sub-section.

\subsection{The Household Hunger Scale (HHS)}

The HHS is an experience-based measure of food security derived directly from qualitative perceptions of rural households regarding their hunger status. This index captures the hunger-related aspects of insecure food access and deployed on the assumption that the intensity of food insecurity is culturally invariant and occurs across multiple sociocultural contexts and can therefore be used to measure food insecurity among farm households in poor regions (Brück, \& d'Errico, 2019). The literature cites the HHS as a unique and practical tool for measuring rural household food insecurity and by far the most important index of measuring food security by access (Swindale, \& Bilinsky, 2006).

\subsection{Household Food Insecurity and Access Scale (HFIAS)}

The HFIAS food security index measures the impact of food insecurity among rural households. It uses a brief survey instrument to assess whether rural households have experienced problems with accessing food during the previous 30 days of the interview date (Hidrobo, Hoddinott, Kumar, \& Olivier, 2018). The index was constructed by the USAID-funded FANTA project, based on a set of generic occurrence questions, grouped by domain and based on the idea that the direct experience of food insecurity by access or deprivation can be quantified through survey (Deitchler et al., 2011). This indicator is used to classify rural household poverty based on their levels of food vulnerability and deprivation (Coates, Swindale, \& Bilinsky, 2007b).

\subsection{Coping Strategies Index (CSI)}

The CSI index was developed by the World Food Programme to measure food access at the household and individual levels (Biederlack \& Rivers, 2009). The index employs a series of questions about how rural households adapt to food deprivation and shortfalls in food supply (FAO et al., 2018). The CSI is a much quicker, simpler, and cheaper way of establishing the food vulnerability and resilience of households to food insecurity. It is an appropriate tool for measuring food security status of rural households under emergency situations such as conflicts and natural disasters (Brück, \& d'Errico, 2019). In areas prone to outbreaks of diseases and inter-ethnic conflicts such as in many areas of 
Sub-Saharan-Africa, the CSI serves as an early warning indicator of an impending food crisis, and also helps to identify priority households in emergency food distribution interventions.. It may also be used to determine whether food security status of rural households is declining or improving over a certain period of time. The CSI index is also useful for monitoring long-term trends of food insecurity among rural households.

\subsection{Household Dietary Diversity (HDD)}

The HDD index measures the ability of a rural household to acquire sufficient quality of meals to meet the nutritional requirements of all members of the household for productive lives (Abebaw et al., 2020; Coates, 2015). Household dietary diversity, defined as the number of unique foods consumed by household members over a given period, has been validated to be a useful approach for measuring rural household food insecurity caused by food deprivation and limited access to food (Wiesmann et al., 2008). The HHD provides an approach to collecting and measuring household dietary diversity as a proxy measure of food security among households.

\subsection{Food Consumption Score (FCS)}

The FCS index is a composite score derived from a computation of the relationship between dietary diversity, food frequency, and relative nutritional importance of different food groups consumed by rural householders (Simmons, 2017). The food security status of rural households can be measured by soliciting from respondents their frequency of consumption (in days) over a recall period of the past 7 day (Swindale \& Bilinsky, 2006). Food items are grouped into eight standard food groups with a maximum value of seven days/week. The consumption frequency of each food group is multiplied by an assigned weight that is based on its nutrient content (Coates, Swindale, \& Bilinsky, 2007b). Based on these computations the FSC thresholds for different households are established. These thresholds range from poor food consumption score, borderline consumption score and the acceptable consumption score (Kennedy, Ballard, \& Dop, 2011).

\subsection{Self-Assessment Measures}

This approach to measuring household food security is highly subjective in nature but easy to quickly compute (Headey \& Ecker, 2012). Self-assessment measures include self-assessment of existing food security status in a recent recall period and change in livelihood status (Coates, 2015). These measures have been introduced in recent years with emphasis on individual and household levels of food security by access.

\subsection{Anthropometric Measure}

The Anthropometric measure is quite from different from other indicators of food security. This measure focuses on the outcomes of food and nutritional security at the individual level within the household. It evaluates the extent to which different household agents (infants, children, adolescents, adults, pregnant and lactating women, and the elderly) meet their individual requirements for productive livelihoods (Uchendu, \& Abolarin, 2015). A wide variety of anthropometric measures exist; the most common ones are weight-for-height (wasting), weight-for-age, and height-for-age (stunting) (De Haen, Klasen, \& Qaim, 2011).

\subsection{Global Hunger Index (GHI)}

The Global Hunger Index (GHI) was designed by the International Food Policy Research Institute (IFPRI) and evaluates food security at the macro level (global, regional, national and district levels) using specifically designed hunger scales (Global Hunger Index, 2019). GHI calculates the hunger scores of households based on progress and setbacks encountered each year in combating food insecurity (Wegenast \& Beck, 2020). It is a food security index helps to allocate resources to countries in greater need of capital inputs to eliminate food and nutritional insecurity (Ballard et al., 2011). The GHI combines three equally weighted indicators as an arithmetic mean to indicate the food security of a country: (1) the proportion of people in that country with insufficient dietary intake, as estimated by FAO; (2) the prevalence of underweight children under the age of five as compiled by the World Health Organization (WHO); and (3) the under-five mortality rate recorded in the country over the last few years (Wegenast \& Beck, 2020).

\section{Political Economy of Sustainable Food Security}

Political economy analysis is increasingly becoming central to the global efforts of achieving sustainable economic growth through the enhancement of welfare outcomes for low-income households. The general idea surrounding new political economy debates for resilience against COVID-19 pandemic is well illustrated in institutional economic theory which promotes the application of the sustainable livelihood framework concepts and structulism theories to food security analysis and implementation in rural Africa (Sen, 1987). The framework addresses the principal contribution of sustainable access to productive resources and other household factor endowments (Chambers \& 
Conway, 1992). Sustainability here implies that livelihood strategies generate adequate incomes for food security or still able to cope with environmental fluctuations of climate change, social and economic stresses of market failure. Sustainable food security therefore depends on availability of critical factor endownments required to produce adequate incomes for buying enough food and protection against natural shocks of the environment. In a political economy of limited opportunities, it also relates to the dynamic influence of gender-based theories in the determination of access to factor endownments. The structuralism function of political economy analysis simply denotes the idea that dominant social groups shape quality of access and opportunities to productive resources within a nation state (Anaman, 2018). Consequently, less dominant groups are marginalized in the determination of access and distribution of opportunities.

However, the notion of political economy goes beyond just access and opportunities to resources. It defines the gateway through which access to opportunities may be effectively utilized and optimized by the poor. This is important as the gateway of access becomes liable to contestations, negotiations and conflicts. Ethnic groups that lack strong social networks and political capital often fail in the access- negotiations which futher undermines their ability to be food secure in a politically dynamic environment (Gershon, Ansah, Marfo \& Donkoh, 2020).

In otherwords, the combinative impact of the political and social forces of food production can not be disputed in food security analysis of the rural poor (Ickowitz, Powell, Roland, Jones, \& Sutherland, 2019). Depending on householders access to specific types of productive resources and capital inputs, four forms of food security outcomes may be distinguished. These are: (1) Weather-Capital Food Security (2) Intellectual-Capital Food Security (3) Remittance- Capital Food Security (4) Social-Capital Food Security (Marafa, May \& Tenebe 2020; Chambers, 1988; Scoones, 1998; Li, Deng, \& Zhou 2019; Salifu, 2019).

\subsection{Weather-Capital Food Security}

Weather-capital food security is sustainable when the environmental and natural capital resources used in food production are adequate to sustain household production throughout the season. It therefore focuses on the role of the environment and other natural capital endowments in enhancing food production. Weather-capital food security is critical to rural households prone to harsh climate change events as new studies indicate that Africa's rain-fed food production would decline by $50 \%$ as a result of climatic change. The role of the weather cannot be ignored in agricultural production ecosystems prone to disaster and cyclical occurrence of weather shocks such as el-ninos, droughts and floods. Achieving food security under these harsh conditions means adjusting livelihood strategies to cope with the attendant effects of the weather on food production outcomes.

In dry areas of the Sahel and Savanna parts of sub-saharan Africa, households are constantly exposed to biotic and abiotic stresses of the degradable nature of their environments. The coping strategies and responses they adapt to these stresses and shocks within the natural ecosytems determine their capabilities for meeting present and future food security goals. For instance, the capacity of the agricultural ecosystem to withstand limiting and devastating effects of weather variables such as el-ninos, droughts and bush fires may be critical in predicting household resilience and food security status (Loison, 2019). Resilient households that are well endowed with natural capital assets such as soils and biodiversity are better able to adjust to the harsh conditions of weather as opposed to poorly endowned households with little or no capital inputs. In the analysis of the food production capabilities and food security of households in rural Africa, the role of weather capital endownments on productivity and consumption patterns of rural households cannot be underestimated in the light of climate variability (Lovo \& Veronesi, 2019). Household's with low weather capital endownments struggle to adjust to the vagaries of bad weather, insect invasion, fall army worm attacks, animal diseases and land degradation. Households vulnerable to these weather effects and biotic attacks are at greater risk of experiencing total crop failure and chronic food insecurity.

\subsection{Intellectual-Capital Food Security}

The role of the intellect cannot be underestimated in the determination of food security status of households. The evidence in rural Africa clearly shows that households endowed with intellectual capital experience little incidences of chronic food insecurity. The educational status of the household head such as access to salaried work has direct impact on household consumption patterns through improved market access (Malang \& Holzinger, 2020). This empirical analysis points to a sharp correspondence between years of schooling attained by household head and food security status of the household. Where the literature is explicit, years of training acquired in a post-secondary technical institute is a key driver of food security in rural Africa (McMillan, Rodrik, \& Sepulveda, 2017).

The failure of African governments to improve access to post-secondary technical education surely undermines global efforts of combating food insecurity and therefore constitutes vocational injustice to rural people (Meraner, 
Pölling, \& Fingera, 2018). This scenario is well depicted in the declining share of public expenditure on vocational training of rural households (Michler \& Josephson, 2017). In Ghana and many parts of Africa, the abolition of technical education in favour of free SHS policies, exacerbates food insecurity for the youth and reduces the capability of rural households to acquire the requisite entrepreneurial skills in agribusiness for climbing out of poverty. The development of new commodity value chains through promotion of agribusiness and entrepreneurship for African graduates is key to food security enhancement in the developing world. Adequate training of teeming unemployed youth in technical-vocational disciplines would significantly improve food security and consumption patterns.

\subsection{Remittances-Capital Food Security}

When crop production fails, remittance plays a crucial role in smoothening consumption patterns of rural households. The financial capital provided by remittance improves household expenditure on food and supports investment into new income generating activities. Investment into new economic activities become necessary as market failure and low incomes threaten agricultural activities. Remittance capital gurantees food security by the cushioning effect it provides poor households against food price shocks and economic unrest as COVID-19 advances globally.

Not all, food security in modern times is severely driven by real incomes and purchasing power of incomes. Thus, low-income heterogenous households unable to accumulate modest assets from remittance capital are at a greater risk of experiencing food poverty, starvation and destitution as income effects impact consumption patterns in rural Africa (Mulwa, \& Visser, 2020).

The Food poverty trends in rural Africa continue to grow dramatically as COVID-19 accentuates the horrifying experiences of poor households characterised by high debt, unstable housing and untreated medical conditions (Morris, Henley \& Dowell, 2017). The outbreak of the COVID-19 pandemic has undoubtedly increased the cost of food and declined living standards of rural households in the developing world. Remittance incomes would be important less resilient households as cost of the food basket rises in the midst of global pandemics.

\subsection{Social- Capital Food Security}

Social-capital food security recognizes the significant role of social networks in building adaptative capacities of households to respond to threats of food insecurity. The literature argues that social relations and business ties influence household welfare and consumption patterns (Mwambo, Fürst, Nyarko, Borgemeister, \& Martius, 2020).The development literature goes on to elaborate that as rural societies become more complex, they develop new linkages which increase their participation in communal network engagement leading to food security, social welfare and achievement of the common good under food crises. In otherwords, the extent to which low-income households participate in the decision- making processes affecting their livelihoods such as solidarity, trust and tolerance are vital determinants of food security in socially-oriented cultures of Africa (Nakajima, Otsuka \& Yamano, 2018).

Within the context of food security it is hypothesized that social capital as a dynamic predictor of food security exceeds the power of any other capital in eliciting food security outcomes. This is because well networked communities experience low incidence of conflicts and tensions which drive vulnerability and food deprivation. In most parts of the Africa, civil strife and conflicts have aggravated food crises for many populations. In a political economy, the failure of the state to guarantee civil rights of socially-disadvantaged-households trapped in inter-regional conflicts as in several parts of West Africa, represents a fatal case of prolonged food deprivation and starvation (Nyaaba \& Bob-Milliar, 2019).

The state has a solemn duty to provide adequate social benefits, claims and safety nets such as gifts, social security packages, cash transfers, affordable housing and other social contracts to rehabilitate households torn by food insecurity, conflicts and social dissension (Odijie, 2020). For relatively peaceful societies, Social capital development enhanced through promotion of protectionist mechanisms for the vulnerable could well secure redistributive food justice for food insecure households.

\section{Political Economy Drivers of Food Security}

The political economy approach to food security provides an analytically vigorous approach for re-alligning low-income households to new transformative opportunities for improving food security in their given context (Abebaw, Admassie, Kassa, \& Padoch, 2020). Political economy analysis argues that rural households are better placed to receive greater opportunities when inclusive policies are incorporated into the design of food security programmes for rural poor. This resolves the major problem of food insecurity accentuated by exclusive development policies that accrue greater benefits to identical political groups while marginalizing segments of the voiceless rural 
populations (Qiu, Zhu, Pan, Wu, Dang ., Xu, \& Yang, 2020).

The identification of the political economy drivers of food security gained through deeper engagement of the factors influencing rural welfare outcomes reveals important determinants of food security (Maxwell, 1990; Anaman \& Bukari, 2019). These include; 1) wage-employment shocks, 2) productive capital- input shocks, 3) output shocks, 4) Global food shocks, and 5) COVID-19 pandemic shocks (Radosavljevic et al., 2020).

\subsection{Productive Capital Input Shocks}

Productive capital input shocks relate to the extreme weather occurrences which limit environmental incomes and increase vulnerability of low-income households engaged in high-risk agricultural production (Cameron \&Worwick, 2003). While the existing literature identifies several idiosyncratic and uncertain income stresses which influence food insecurity, it fails to identify the effect of unanticipated crop losses and livestock income sources as major predicators of food poverty (Rahman \& Mishra, 2020). For instance, unanticipated income losses from a sudden drop in livestock capital due to sudden outbreak of animal diseases such as anthrax in cattle can significantly drive up food insecurity. The sudden seizure of animal assets, quite common in rural areas, can also lead to starvation of affected farm families. Over a period of time the cumulative effects of these unanticipated losses significantly pose the greatest threat to food security in rural Africa (Rodgers, Bebbington, Boone, Dell'Angelo, Platteau, \& Agrawal; 202)

\subsection{Off-farm Employment Shocks}

Off-farm employment is an important driver of rural food security in the lean season when food production declines. Low-income households engage in casual off-farm wage-labour employment to earn additional incomes to support household consumption when food scarcity increases. Household food consumption is tied to the seasonal changes in labour demand for permanent off-farm jobs (Shoeb-Ur-Rahman, Simmons, Shone \& Ratna, 2020). The sudden changes in demand for farm wage labour reduce off-farm earnings and increases food poverty and hunger. The literature notes that, while female headed households are forced to participate in extremely costly income generation activities such as wood fetching and charcoal burning which have tremendous effects on the environment and agroecological ecosystems (Severini, Biagini, \& Finger, 2020), male headed households are forced to take up less profitable and low-return income activities that do not only accrue minimal incomes to households but actually pose a significant threat to livelihoods (Sen, 1984; Simmons, 2017).

\subsection{Agricultural Output Shocks}

Agricultural output shocks sincerely undermine household strategies for improving food security and future consumption. The effect of agricultural output shocks on food security is accentuated by the geopolitical climate change events sweeping the continent (Tran, \& VanVu, 2019). The sudden decline in production output of food and non-food crops and products over the last decade due to persistent insect-invasion and fall armyworm infestations in certain parts of sub-saharan Africa have significantly decreased household resilience to food insecurity, increasing vulnerability and poverty for affected households (Cissé, Upton,. et al.2020).

\subsection{Global Food Shocks}

Global food stocks influence local food stocks and prices in agricultural commodity markets (Wang, Yau, Hua, \& Yang, 2019). Rising food prices, food price volatilities and geopolitical unrest on the international front have price hikes implications for local food consumption. These sudden changes are greatly felt by African food markets that rely on consistent food supplies from the global food markets. The food dependency ratio is particularly high for African economies that have not achieved national food self-sufficiency, self-reliance and sovereignty in cereal crop production. For instance, Ghana as a low-middle income country is still not self-sufficient in staple food production. Food production has often fluctuated between glut and scarcity. This condition is worsened by a sudden proliferation of staple food prices on the global markets that feed local supplies in Africa and the developing world.

Global trade and export restrictions on certain key commodities of African economies pose a major threat to food security (Wegenast \& Beck, 2020). The responses of governments and markets to these global supply shocks determine the duration of food crises in poorer regions of the world (FAO, 2018). The intensity of the devastating effects of global food shortages on local consumption has no correlation with whether the local country is a net producer of food or not (FAO, 2019).

\subsection{The COVID-19 Shock}

The sudden rise of COVID-19 cases in Africa and other parts of the world has sent food alarm and panic waves across many regions of the developing world (Narayanan, 2020). The pandemic has generated very significant 
shocks in productive capacity, purchasing power and per capita food availability for vulnerable households already experiencing annual food shortages due to weather change events (Laborde, Martin \& Vos, 2020). The disruption of rural non-farm economy by strict quarantining of households has created a major problem in global food supply stocks and gradually increased rural food insecurity and poverty (Devereaux, Bene, \& Hoddinott, 2020). The entire social and marketing systems of rural household enterprises have been crashed by lock down protocols from central governments. The strict protocols of social distancing have negatively impacted the global food supply chains and aggravated the condition of global food poverty (Bene, 2020). The link between household consumption welfare and vulnerability to COVID-19 pandemic may be critical in modelling food security statutes of rural households (Harvard T.H. Chan School of Public Health, 2020).

\section{Conclusion}

This paper provides a summary of the theoretical concepts of food security and shows how low-income households around the world respond to the varied forms of global crises based on an extensive review of 120 empirical studies compiled and synthesized from all continents of the world. In synthesizing across different empirical studies of food security, certain thematic areas of interest have been considered in this context. Although other dimensions of food security such as food trade and prices, food consumption cultures and ethical consumerism, retail sector of food distribution and food aid exist, the review has largely been on the international political economy of food security and development issues in rural Africa. The review leans towards broader international politics of the food economy with some paradoxical conclusions for the revision of approaches to food security implementation and internalization. First, there is growing global convergence of conceptual transition of food security goals from mere "access to enough food", to "access to the preffered food". Traditional food security concepts have addressed national self-sufficiency perpectives of food security but fail to take into account the multiple forces which come to play to affect individual access to food. The polical economy analysis shows that, at the individual level, food security is experienced in gendered, racialized, and otherwise inequitable ways. The review identifies and illustrates different problematiques for a comprehensive understanding of the international political economy of food security. The paper combines different perspectives of food security grounded in different theorectical traditions, and conceptions of power. Second, the micropolitics of food that work in different constellations of ethnic power to perpetuate food insecurity are well articulated. This suggests the importance of empowerment of the voiceless and the powerless in the design of sustainable food security interventions. Third, the review focuses on the value of intergrating the dimensions of politics and power into food security analysis, given that access to opportunities are determined by dorminant groups of society who exert control over social resources and opportunities. Finally, the review identifies several welfare gaps arising from limited and uncertain access to productive inputs needed to secure enough preffered food. Sustainable reconceptualization of food security through political economy analysis is compelling in the face of Covid-19 which increases vulnerability and food poverty. The paper identifies a revisionist approach to food security as an alternative approach to addressing food security problematiques, acknowledging the possibility of multiple pathways to transformational enhancement of food security in sub-saharan Africa.

\section{References}

Abebaw, D., Admassie, A., Kassa, H., \& Padoch, C. (2020). Can rural outmigration improve household food security? $\begin{array}{llllll}\text { Empirical evidence from Ethiopia. World Development, } & 129, & 104879 .\end{array}$ https://doi.org/10.1016/j.worlddev.2020.104879

Adjei, P. O. W., Adjei, J. O., \& Serbeh, R. (2020). Looking beyond cash transfers for optimizing poverty reduction and livelihood sustainability in rural Ghana: Comparative analysis of two socialpolicy interventions against poverty. Poverty and Public Policy, 12(1), 84-111. https://doi.org/10.1002/pop4.270

Ahmed, A., \& Gasparatos, A. (2020). Multi-dimensional energy poverty patterns around industrial crop projects in Ghana: Enhancing the energy poverty alleviation potential of rural development strategies. Energy Policy, 137, 111123. https://doi.org/10.1016/j.enpol.2019.111123

Alcona, F., Marín-Miñanoa, C., Zabalaa, J. A., Doloresde-Miguela, M., \& Martínez-Paz, J. M. (2020). Valuing diversification benefits through intercropping in Mediterranean agroecosystems: A choice experiment approach. Ecological Economics, 171, 106593. https://doi.org/10.1016/j.ecolecon.2020.106593

Alpízar, F., Saborío-Rodríguez, M., Martínez-Rodríguez, M. R., et al.. (2020). Determinants of food insecurity among smallholder farmer households in Central America: recurrent versus extreme weather-driven events. Reg Environ Change, 20, 22. https://doi.org/10.1007/s10113-020-01592-y

Anaman, K. A. (2018). Economic Shocks and Growth in the Post-Independence Period, 1957 to 2017. Accra: Institute of Fiscal Studies. 
Ashley, C., \& Carney, D. (1999). Sustainable livelihoods: Lessons from early experience. London: Department for International Development (DFID).

Balana, B. B., Bizimana, J., Richardson, J. W., Lefore, N., Adimassa, Z., \& Herbst, B. K. (2020). Economic and food security effects of small-scale irrigation technologies in northern Ghana. Water Resources and Economics, 29, 100141. https://doi.org/10.1016/j.wre.2019.03.001

Baliki, G., Brück, T., \& Stojetz, W. (2018). Drivers of resilience and food security in North-east Nigeria: Learning from micro data in an emergency setting. ISDC, Berlin.

Bellon, M. R., Kotu, B. H., Azzarri, C., \& Caracciolo, F. (2020). To diversify or not to diversify, that is the question. Pursuing agricultural development for smallholder farmers in marginal areas of Ghana. World Development, 12, 104682. https://doi.org/10.1016/j.worlddev.2019.104682

Béné, C. (2020). Resilience of local food systems and links to food security - a review of some importantconcepts in the context of COVID-19 and other shocks. Food Security. https://doi.org/10.1007/s12571-020-01076-1

Bickel, G. W., Andrews, M. S., \& Klein, B. W. (1996). Measuring food security in the United States: a supplement to the CPS. In D. Hall, \& M. Stavrianos (Eds.), Nutrition and Food Security in the Food Stamp Program USD a food and consumer service. Alexandria, VA.

Bickel, G., Nord, M., Price, C., Hamilton, W., \& Cook, J. T. (2000). Measuring food security in the United States: Guide to measuring household food security, rev. 2000 USDA/FNS/OAE Alexandria, VA.

Biggs, E. M., Gupta, N., Saikia, S. D., \& John, M. A. D. (2018). The tea landscape of Assam: Multi-stakeholder insights into sustainable livelihoods under a changing climate. Environmental Science \& Policy, 82, 9-18. https://doi.org/10.1016/j.envsci.2018.01.003

Bisht, I. S., Rana, J. C., \& Ahlawat, S. P. (2020). The future of smallholder farming in India: Some sustainability considerations. Sustainability, 12(9), 3751. https://doi.org/10.3390/su12093751

Boamah, E. F., \& Sumberg, J. (2019). The long overhang of bad decisions in agro-industrial development: Sugar and tomato paste in Ghana. Food Policy, 89, 101786. https://doi.org/10.1016/j.foodpol.2019.101786

Brück, T., \& D'Errico, M. (2019). Food security and violent conflict: Introduction to the special issue. World Development, 117, 167-171. https://doi.org/10.1016/j.worlddev.2019.01.007

Cai, J., Ma, E., Lin, J., et al.. (2020). Exploring global food security pattern from the perspective of spatio-temporal evolution. J. Geogr. Sci., 30, 179-196. https://doi.org/10.1007/s11442-020-1722-y

Call, M., Gray, C., \& Jagger, P. (2019). Smallholder responses to climate anomalies in rural Uganda. World Development, 115, 132-144. https://doi.org/10.1016/j.worlddev.2018.11.009

Castro-Arce, K., \& Vanclay, F. (2020). Transformative social innovation for sustainable rural development: An analytical framework to assist community-based initiatives. Journal of Rural Studies, 74, 45-54. https://doi.org/10.1016/j.jrurstud.2019.11.010

Chamberlina, J., \& Jayne, T. S. (2020). Does farm structure affect rural household incomes? Evidencefrom Tanzania. Food Policy, 90, 101805. https://doi.org/10.1016/j.foodpol.2019.101805

Chambers, R., \& Conway, G. (1992). Sustainable rural livelihoods: practical concepts for the 21st century. IDS Discussion Paper 296, Institute of Development Studies, Brighton, Sussex, UK.

Coates, J. (2015). Food insecurity measurement. Food Ins. Pub. Health, 51-64. https://doi.org/10.1201/b18451-4

Coates, J., Swindale, A., \& Bilinsky, P. (2007b). Household food insecurity access scale (Hfias) for measurement of food access: indicator guide. Washington, dc: food and nutrition technical assistance project. Academy for Educational Development, 34. https://doi.org/10.1037/e576842013-001

Colebatch, H. K. (2017, May). The Idea of Policy Design: Intention, Process, Outcome, Meaning and Validity. Public Policy and Administration, (18), 365-383. https://doi.org/10.1177/0952076717709525

D’Errico, M., Romano, D., \& Pietrelli, R. (2018). Household resilience to food insecurity: evidence from Tanzania and Uganda. Food Security, 10(4), 1033-1054. https://doi.org/10.1007/s12571-018-0820-5

Dapilah, F., Nielsen, J. O., \& Friis, C. (2020). The role of social networks in building adaptive capacity and resilience to climate change: a case study from northern Ghana. Journal of Climate and Development, 12(1), 42-56. https://doi.org/10.1080/17565529.2019.1596063

Dary, S. K., \& Ustarz, Y. (2020). Internal remittances and employment choices in rural Ghana. African Journal of Economic and Management Studies. https://doi.org/10.1108/AJEMS-03-2019-0126 
Davis, B., Di Guiseppe, S., \& Zezza, A. (2017). Are Africans (not) leaving agriculture? Patterns of household income sources in rural Sub-Saharan Africa. Food Policy, 67, 153-174. https://doi.org/10.1016/j.foodpol.2016.09.018

Deaton, B. J., \& Lipka, B. (2015). Political instability and food security. Journal of Food Security, 3(1), 29-33. https://doi.org/10.12691/jfs-3-1-5.

Devereux, S., Béné, C., \& Hoddinott, J. (2020). Conceptualising COVID-19's impacts on household food security. Food Sec., 12, 769-772. https://doi.org/10.1007/s12571-020-01085-0

Diao, X., Magalhaes, E., \& Silver, J. (2019). Cities and rural transformation; a spatial analysis of rural livelihoods in Ghana. World Development, 121, 141-157. https://doi.org/10.1016/j.worlddev.2019.05.001

Dillon, B., \& Barrett, C. B. (2017). Agricultural factor markets in Sub-Saharan Africa: An updated view with formal tests for market failure. Food Policy, (67), 64-77. https://doi.org/10.1016/j.foodpol.2016.09.015

Ding, Z., \& Abdulai, A. (2020). An analysis of the factors influencing choice of microcredit sources and impact of participation on household income. Journal of International Development. https://doi.org/10.1002/jid.3466

Dithmer, J., \& Abdulai, A. (2017). Does trade openness contribute to food security? A dynamic panel analysis. Food Policy, (69), 218-230. https://doi.org/10.1016/j.foodpol.2017.04.008

Djido, A. I., \& Shiferaw, B. (2018). Patterns of labour productivity and income diversification-Empirical evidence from Uganda and Nigeria. World Development, 105, 416-427. https://doi.org/10.1016/j.worlddev.2017.12.026

Durão, S., Visser, M., Kredo, T., et al.. (2020). Assessing the completeness and comparability of outcomes in systematic reviews addressing food security: protocol for a methodological study. Syst Rev, 9, 9. https://doi.org/10.1186/s13643-019-1268-1

Dzanku, F. M. (2019). Food security in rural sub-Saharan Africa: Exploring the nexus between gender, geography and off-farm employment. World Development, 113, 26-43.

Dzanku, F. M., \& Sarpong, D. (2011). Agricultural diversification, food self-sufficiency and food security in Ghana. CABI, Wallingford, UK Google Scholar. https://doi.org/10.1016/j.worlddev.2018.08.017

Ecker, O. (2018). Agricultural transformation and food and nutrition security in Ghana: Does farm production diversity (still) matter for household dietary diversity?. Food Policy, 79, 271-282. https://doi.org/10.1016/j.foodpol.2018.08.002

Eide, A. (1986). Rights to adequate food as a human right. Centre for Human Rights. Geneva.

Evans, A. (1991). Gender issues in rural household economics. IDS Bulletin, 22(1), 51-59. https://doi.org/10.1111/j.1759-5436.1991.mp22001008.x

FAO, IFAD, UNICEF, WFP, \& WHO. (2018). The State of Food Security and Nutrition in the World 2018. Building climate resilience for food security and nutrition. FAO, Rome.

FAO, IFAD, UNICEF, WFP, \& WHO. (2019). The State of Food Security and Nutrition in the World 2018: Safeguarding against economic slowdowns and downturns. FAO, Rome.

Faulkner, J., Murphy, E., \& Scott, M. (2019). Rural household vulnerability; a decade after the great financial crisis. Journal of Rural studies, 72(1), 240-251. https://doi.org/10.1016/j.jrurstud.2019.10.030

Fentahun, G. E., Seid, S., \& Biruk, K. (2018). The role of income diversification on risk management and rural household food security in Ethiopia. Journal of Economics and Sustainable Development, 9(9).

Forero-Cantor, G., Ribal, J., \& Sanjuán, N. (2020). Measuring regional differences in food security from access and stability dimensions: A methodological proposal based on elasticities. Agric. Econ. Czech, 66, 112-119. https://doi.org/10.17221/97/2019-AGRICECON

Gershon, I., Ansah, K., Marfo, E., \& Donkoh, S. A. (2020). Food demand characteristics in Ghana: An application of the quadratic almost ideal demand systems. Scientific African, 8, e00293. https://doi.org/10.1016/j.sciaf.2020.e00293

Headey, D. (2013). Developmental drivers of nutritional change: A cross-country analysis. World Development, 42(2), 76-88. https://doi.org/10.1016/j.worlddev.2012.07.002

Hindle, R. F. (1990). The World Bank approach to food security analysis. IDS Bulletin, 21(3), 62-66. https://doi.org/10.1111/j.1759-5436.1990.mp21003007.x

Johny, J., Wichmann, B., \& Swallow, B. M. (2017). Characterizing social networks and their effects on income diversification in rural Kerala, India. World Development, 94, 375-392. https://doi.org/10.1016/j.worlddev.2017.02.002 
Kahsay, S., \& Mulugeta, M. (2014). Determinants of rural household food insecurity in Laelay Maichew Woreda Tigray. Ethiopia. Afr J Agric Food Security, 2(1), 105-111.

Kirk, A., Kilic, T., \& Carletto, C. (2018). Composition of household income and child nutrition outcomes evidence from Uganda. World Development, 109, 452-469. https://doi.org/10.1016/j.worlddev.2017.03.023

Laborde, D., Martin, W., \& Vos, R. (2020). Poverty and food insecurity could grow dramatically as COVID-19 spreads. Blog published by the International Food Policy Research Institute (IFPRI). https://doi.org/10.2499/p15738coll2.133762_02

Lang, T., \& Barling, D. (2012). Food security and food sustainability: Reformulating the debate. The Geographical Journal, 178(4), 313-326. https://doi.org/10.1111/j.1475-4959.2012.00480.x

Lax, J., \& Köthke, M. (2017). Livelihood strategies and forest product utilisation of rural households in Nepal. Small-scale Forestry, 16(2), 1-16. https://doi.org/10.1007/s11842-017-9367-0

Malang, T., \& Holzinger, K. (2020). The political economy of differentiated integration: The case of common agricultural policy. The Review of International Organizations. https://doi.org/10.1007/s11558-020-09384-z

Marafa, L., May, J., \& Tenebe, V. A. (2020). Upscaling agriculture and food security in africa in pursuit of the SDGs: What role does China play?. In M. Ramutsindela, \& D. Mickler, (Eds.), Africa and the Sustainable Development Goals. Sustainable Development Goals Series. Springer, Cham. https://doi.org/10.1007/978-3-030-14857-7_16

Masset, E., García-Hombrados, J., \& Acharya, A. (2020). Aiming high and falling low: The SADA-Northern Ghana Millennium Village Project. Journal of Development Economics, 143, 102427. https://doi.org/10.1016/j.jdeveco.2019.102427

Maxwell, S. (1990). Food security in developing countries; issues and options for the 1990s. IDS Bulletin, 22(3), 2-13. https://doi.org/10.1111/j.1759-5436.1990.mp21003002.x

Meraner, M., Pölling, B., \& Fingera, R. (2018). Data on farm diversification decisions and farmers' risk preferences in the Ruhr Metropolitan region (Germany). Data in Brief, 18, 9-12. https://doi.org/10.1016/j.dib.2018.03.008

Moniruzzaman, M. (2020). The Impact of remittances on household food security: Evidence from a survey in Bangladesh. Migration and Development. https://doi.org/10.1080/21632324.2020.1787097

Mubaya, C. P., \& Mafongoya, P. (2016). Local-level climate change adaptation decision-making and livelihoods in semi-arid areas in Zimbabwe. Environment Development \& Sustainability, 19(6), 1-27. https://doi.org/10.1007/s10668-016-9861-0

Muhammed, A. (1987). Present Situation and Future outlook for Food Security in the Muslim World in Food security in the Muslim World, proceedings of the seminar on food security in the Muslim world, organised by Islamic Academy of Sciences. Amman, Jordan, 5-7, December.

Mulwa, C. K., \& Visser, M. (2020). Farm diversification as an adaptation strategy to climatic shocks and implications for food security in northern Namibia. World Development, 129, 104906. https://doi.org/10.1016/j.worlddev.2020.104906

Nakajima, M., Otsuka, K., \& Yamano, T. (2018). Jobs off the farm: wealth, human capital, and social group in rural eastern India. Journal of Development studies, 54(1), 111-132. https://doi.org/10.1080/00220388.2017.1283017

Narayanan, S. (2020). Food and agriculture during a pandemic: Managing the consequences. Blog published by Ideas for India.

Oshaug, A. (1985). The Composite Concept of Food security in Eide W.B. etal. 1985, Introducing Nutritional Considerations into Rural Development Programmes with focus on Agric. A theoretical contribution, Development of Methodology for Evolution of Nutritional Impact research, University of Oslo, June.

Oxford Policy Management (OPM). (2017). Shock-responsive social protection systems research: Literature review. Oxford: Oxford Policy Management.

Porter, C. (2012). Shocks, consumption and income diversification in rural Ethiopia. Journal of Development Studies, 48(9), 1209-1222. https://doi.org/10.1080/00220388.2011.646990

Pritchard, R., Grundy, I. M., Horst, D., \& Ryan, C. M. (2019). Environmental incomes sustained as provisioning ecosystem service availability declines along a woodland resource gradient in Zimbabwe. World Development, 122, 325-338. https://doi.org/10.1016/j.worlddev.2019.05.008

Raphael, D. D. (1967). Political theory and rights of man. Macmillan London. 
Ravallion, M., \& Chaudhuri, S. (1997). Risk and insurance in village India: comment. Econometrica, 65(1), 171-184. https://doi.org/10.2307/2171818

Salifu, G. A. N. (2019b). The political economy dynamics of rural household income diversification: Review of the international literature. Research in World Economy, 10(3), 10-34. https://doi.org/10.5430/rwe.v10n3p273

Salifu, G. A. N. (2020). Political Economy Analysis of Income Diversification Activities of Rural Households and Food Security: A Case Study of Yendi and Nanumba North Districts of the Northern Region of Ghana. Unpublished Doctoral thesis, Department of Agricultural Economics and Agribusiness, University of Ghana. https://doi.org/10.11114/aef.v6i5.4405

Salifu, G. A. N. (2021). Picking the right arrow for the target: modelling economic impact of agribusiness entreprenuership and rural unemployment in Sub-Saharan Africa. Business and Management Research, 10(1), 10-34. https://doi.org/10.5430/bmr.v10n1p18

Salifu, G. A. N. (2021). The Proof of Economic Welfare is in the Eating of Nutritious diets by resource-poor; A Political Economy Analysis of the International Evidence of Dietary Consumption in Rural Africa. International Journal of Business Administration, 12(1), 10-34. https://doi.org/10.5430/ijba.v12n1p57

Salifu, G. A. N., \& Anaman, K. A. (2019a). Political Economy Analysis of Income diversification of Rural Households in the Northern Region of Ghana. Applied Economics and Finance, 6(5), 10-34. https://doi.org/10.11114/aef.v6i5.4405

Sarkodie, S. A., \& Adams, S. (2020). Electricity access, human development index, governance and income inequality in Sub-Saharan Africa. Energy Reports, 6, 455-466. https://doi.org/10.1016/j.egyr.2020.02.009

Scoones, I. (1998). Sustainable rural livelihoods: a framework for analysis. Institute of Development Studies (IDS). Brighton, UK. IDS Working Paper 72.

Seidu, A. A., Ahinkorah, B. O., \& Agbablo, E. (2020). Food Insecurity among In-school Adolescents in Ghana: What are the Determinants? Journal of Hunger \& Environmental Nutrition. https://doi.org/10.1080/19320248.2020.1745723

Start, D., \& Johnson, C. (2004). Livelihood options? The political economy of access, opportunity and diversification. Overseas Development Institute (ODI), London, UK. ODI Working Paper 233. Retrieved from http://www.odi.org

Tithy, D., Naznin, S., \& Elias, H. (2017). Analysis of the impact of income diversification strategies on food security status of rural households in Bangladesh: A Case Study of Rajshahi District. American Journal of Theoretical and Applied Business, 2(4), 46-56.

Upton, J. B., Cissé, J. D., \& Barrett, C. B. (2016). Food security as resilience: Reconciling definition and measurement. Agricultural Economics, 47(S1), 135-147. https://doi.org/10.1111/agec.12305

Walelign, S. Z. (2016). Livelihood strategies, environmental dependency and rural poverty: The case of two villages in rural Mozambique. Environment Development \& Sustainability, 18(2), 593-613. https://doi.org/10.1007/s10668-015-9658-6

World Bank. (2020). Brief: Food security and COVID-19.

Wuepper, D., Sauer, J., \& Kleemann, L. (2018). Social capital, income diversification and climate change adaptation: panel data evidence from Rural Ethiopia. Journal of Agricultural Economics, 69(2), 458-475. https://doi.org/10.1111/1477-9552.12237

Yobe, C. L., Mudhara, M., \& Mafongoya, P. (2019). Livelihood strategies and their determinants among smallholder farming households in KwaZulu-Natal province, South Africa. Agrekon, 58(3), 340-353. https://doi.org/10.1080/03031853.2019.1608275

\section{Copyrights}

Copyright for this article is retained by the author(s), with first publication rights granted to the journal.

This is an open-access article distributed under the terms and conditions of the Creative Commons Attribution license (http://creativecommons.org/licenses/by/4.0/). 